\title{
David Oliver: Are hospitals heading the same way as prisons?
}

\section{David Oliver consultant in geriatrics and acute general medicine}

Berkshire

In 2016 England's jails faced riots, ${ }^{1}$ damning inspection reports on conditions, ${ }^{2}$ and tales of ready access to drugs. ${ }^{3}$ The latest and largest riot was at HMP Birmingham, where officers lost control for 48 hours. ${ }^{4}$

Widespread coverage has been given to prison overcrowding, ${ }^{56}$ superannuated buildings, ${ }^{78}$ and prison officers' numbers, workload, and morale. ${ }^{9}$ Unions, campaigning charities, and the inspectorate have flagged concerns repeatedly. ${ }^{10}$

We in NHS hospitals can empathise. Overcrowding, short staffing, and low morale put patients and organisations at risk. Acute activity, overcrowding, and delayed transfers are at unprecedented levels: we're full to bursting. These issues have been highlighted repeatedly but are played down and ducked by the government.

The UK prison population has increased steadily to a 2015 level of 84000 inmates. ${ }^{11}$ This relentless upward trajectory looks much like NHS acute admissions-the response to which has been to cut beds and propose further cuts. Some of the prison overcrowding is a result of changes to sentencing policies. The UK now has one of the highest per capita prison populations in Europe (by contrast, the NHS has almost the lowest hospital bed base), ${ }^{12}{ }^{13}$ but it hasn't matched capacity to demand.

The Prison Service remains short of its own targets for officer numbers. Poor staffing, loss of experience, and inadequate supervision have been cited as key safety factors behind recent troubles. ${ }^{14}$

The outsourcing obsession, familiar to the NHS, has led to serial scandals in facilities run by private contractors

Government policy around building new prison places has been stop-start and has failed to deliver on promised

numbers-compounding overcrowding and risk. We've seen U-turns on proposed moves to giant "Titan" prisons and heard doctrinal debates on optimal institutional size, familiar to anyone studying NHS reconfiguration plans. ${ }^{15}$

Much rhetoric has focused on crime prevention, community solutions, and alternatives to prison. As with the NHS, the government hasn't invested sufficiently in those approaches. The probation officer workforce has been cut, outsourced, and demoralised. ${ }^{16}$ The prevalence of mental illness, learning difficulty or disability, and addiction are far higher in prisons than in the general population. ${ }^{17}$ Inadequate funding for mental healthcare, drug and alcohol services, disability benefits, and public health are the antithesis of prevention.

The outsourcing obsession, familiar to the NHS, has led to serial scandals in facilities run by private contractors. Some, including HMP Birmingham, had to be rescued by public sector teams. Transient ministers have created uncertainty by taking prison policy in very different directions, hawkish or progressive. ${ }^{14-17}$ The Treasury belatedly announced emergency funding only when reputational damage from crises forced its hand. ${ }^{18} 19$ Political expediency trumps steady, long term leadership by expert career professionals. This is no way to run major, national, public services.

NHS hospitals may limp on through this winter. But, with prison-style crises looming, I predict a riot.

Competing interests: See www.bmj.com/about-bmj/freelancecontributors/david-oliver.

Provenance and peer review: Commissioned; not externally peer reviewed.

Follow David on Twitter, @mancunianmedic

British prisons: five major incidents in 12 months. SKY News 23 Dec 2016. http://news. sky.com/story/british-prisons-five-major-incidents-in-12-months-10705422.

2. HM Chief Inspector of Prisons for England and Wales. Annual report 2015-16. $19 \mathrm{Ju}$ 2016. https://www.gov.uk/government/uploads/system/uploads/attachment_data/file/ 571732/hmip-annual-report.pdf.

3 Big rise in drone jail smuggling incidents. BBC News 23 Feb 2016. www.bbc.com/news/ uk-35641453.

4 Evans M, Willgress L. 240 prisoners moved out of HMP Birmingham after "worst riot since Strangeways." Telegraph 17 Dec 2016. www.telegraph.co.uk/news/2016/12/16/prisonriot-breaks-hmp-birmingham/.

5 Hall M. Prisoners may serve sentence just at weekends to ease jail overcrowding. Express 18 May 2016. www.express.co.uk/news/uk/671649/Prisoners-may-serve-sentences-atweekends-ease-overcrowding-Queens-speech.

6 Travis A. UK prison population is biggest in western Europe. Guardian 8 Mar 2016. https: //www.theguardian.com/society/2016/mar/08/uk-prison-population-is-biggest-in-westerneurope. 
7 UK Parliament Website. Prisoner population and overcrowding: key issues for the 2015 parliament. https://www.parliament.uk/business/publications/research/key-issuesparliament-2015/justice/prisoner-population/.

8 James E. Ministers face an uphill battle to reform failing and decrepit jails. Guardian 12 Apr 2016. https://www.theguardian.com/society/2016/apr/12/ministers-prison-reformovercrowded-understaffed-invest.

9 Stone J. Government to recruit 2,500 new prison officers after warning cuts are leaving jails unsafe. Independent 3 Nov 2016. www.independent.co.uk/news/uk/politics/ government-to-recruit-2500-new-prison-officers-after-warning-cuts-are-leaving-jails-unsafea7394141.html.

10 Weaver M. Prison officers' union to resume talks with justice secretary. Guardian 17 Nov 2016. https://www.theguardian.com/society/2016/nov/17/prison-officers-associationresume-talks-justice-secretary-liz-truss.

11 Allen G, Dempsey N. Prison population statistics. (House of Commons Library SN/SG/04334). 4 Jul 2016. http://researchbriefings.files.parliament.uk/documents/SN04334/ SN04334.pdf.

12 Statewatch. Prison capital: UK locks up more people than any other EU member state. 11 Mar 2016. www.statewatch.org/news/2016/mar/coe-prison-statistics-2014.html.

13 Organisation for Economic Co-operation and Development. Health at a glance: Europe 2016. 2016. https://www.oecd.org/health/health-systems/Health-at-a-Glance-EUROPE2016-Briefing-Note-UNITED\%20KINGDOM.pdf.
14 House of Commons Justice Committee. Prison safety-sixth report of session 2015-16. 10 May 2016. www.publications.parliament.uk/pa/cm201516/cmselect/cmjust/625/625. pdf.

5 House of Commons Justice Committee. Prisons: planning and policies-ninth report of session 2014-15. 4 Mar 2015. www.publications.parliament.uk/pa/cm201415/cmselect/ cmjust/309/309.pdf.

16 Rutter T. Privatised probation staff: stressed, deskilled and facing job cuts. Guardian 23 Feb 2016. https://www.theguardian.com/public-leaders-network/2016/feb/23/privatisationprobation-service-stressed-job-cuts.

17 Prison Reform Trust. Prison: the facts-Bromley briefings summer 2016. 2016. www. prisonreformtrust.org.uk/Portals/0/Documents/Bromley\%20Briefings/summer\%202016\% 20briefing.pdf.

18 HM Treasury. Autumn statement 2016. 23 Nov 2016. https://www.gov.uk/government/ publications/autumn-statement-2016-documents/autumn-statement-2016.

19 Maddox D. Chancellor announces recruitment HUNDREDS more prison officers to staff Britain's jails. Express 23 Nov 2016. www.express.co.uk/news/politics/735736/Chancellorrecruitment-HUNDREDS-prison-officers-staff-Britain-jails.

Published by the BMJ Publishing Group Limited. For permission to use (where not already granted under a licence) please go to http://group.bmj.com/group/rights-licensing/ permissions 